ISSN 0258-7122

Bangladesh J. Agril. Res. 40(4): 657-667, December 2015

\title{
EFFICACY OF SOME INSECTICIDES AGAINST INSECT PESTS OF MUNGBEAN (Vigna radiata $\mathbf{L}$.
}

\author{
Md. ALtAF Hossain ${ }^{1}$
}

\begin{abstract}
Efficacy and profitability of insecticidal management practices using different insecticides were tested against insect pests of mungbean at Pulses Research Center, Ishurdi, Pabna, Bangladesh during two consecutive seasons of kharif-1 2013 and 2014. Insect infestations were reduced significantly by the application of synthetic insecticides. Spraying of Imidachloprid (Imitaf $20 \mathrm{SL}$ ) @ $0.5 \mathrm{ml} / \mathrm{l}$ of water showed the best efficacy in reducing flower infestation and thrips population followed by Fipronil (Regent 50 SC). Spraying of Thiamethoxam + Chlorantraneliprol (Voliam flexi $300 \mathrm{SC}$ ) @ $0.5 \mathrm{ml} / 1$ of water showed the best efficacy in reducing pod borer and flea beetle infestations. Spraying of Fipronil (Regent $50 \mathrm{SC}$ ) performed highest efficacy against stemfly infestation. The yield and the highest net return were obtained from Voliam flexi $300 \mathrm{SC}$, the highest benefit was obtained from Regent 50 SC treated plots. This might be due to the higher cost of Voliam flexi that reduced the profit margin and showed the lower marginal benefit cost ratio (MBCR) compared to Regent. Therefore, considering the efficacy and benefit, spraying of Fipronil (Regent $50 \mathrm{SC}$ ) @ $0.5 \mathrm{ml} / 1$ is the most profitable insecticidal management approach against insect pests of mungbean followed by Imidachloprid (Imitaf 20 SL) at the same dose.
\end{abstract}

Keywords: Insecticide, management, insect pests, mungbean

\section{Introduction}

Mungbean (Vigna radiata L.) is one of the important pulse crops in Bangladesh. Due to availability of short duration varieties, farmers are becoming more interested to cultivate this valuable crop after harvesting of rabi crops in kharif-I season. However, insect pests usually cause significant yield loss. More than twelve species of insect pests were found to infest mungbean in Bangladesh (Rahman et al., 2000). Among them, stemfly, flea beetles, flower thrips and pod borers are the most important.

Larvae of stemfly feed inside the main stem and finally tunnels even up to roots. The affected plants have stunted growth with poor yield. The adult flea beetles feed on the cotyledons and leaves of young plants making innumerable round holes. The damaged leaves dried up and the plant growth is rendered with few pods. Thrips (Megalurothrips distalis Karny, Megalurothrips usitatus Bagnall and Caliothrips indicus Bagnall) is associated mostly with the damage of tender buds and flowers of mungbean. Severe infestation of thrips resulted flower shedding causing significant yield loss (Chhabra and Kooner, 1985; Lal, 1985).

${ }^{1}$ Principal Scientific Officer (Entomology) Pulses Research Center, Bangladesh Agricultural Research Institute (BARI), Ishurdi, Pabna, Bangladesh. 
Pod borer is another insect pest causing significant yield reduction. Pod borer (Maruca vitrata) damages flowers, flower buds and developing or mature pods (Poehlman, 1991). In Bangladesh, pod borers (Maruca vitrata, Helicoverpa armigera Hubner and Euchrysops spp.) often cause serious problem resulting severe loss of the crop (Bakr, 1998). Farmers usually do not take any measure to control the insect pests due to its low profit margin. However, recent development of high yielding and short duration varieties and increased market value of mungbean, farmers become interested on the cultivation of mungbean following pest management measures. Due to easy availability of insecticides, farmers generally take action to control mungbean pests by applying synthetic chemical insecticides. Information regarding insecticidal management practices of insect pests in mungbean is not very available. Therefore, it is needed to develop insecticidal management approach to control mungbean pests and save the crop from significant yield loss. Keeping this in view, attempts have been made to evaluate the efficacy of some synthetic insecticides and economics of the management of mungberan insect pests.

\section{Materials and Method}

The experiment was conducted in the Pulses Research Center, Ishurdi, Pabna, Bangladesh during two consecutive seasons of kharif-I 2013 and 2014. Application of synthetic insecticides considered as treatments of the experiments which were: $\mathrm{T}_{1}=$ Spraying Cypermethrin $($ Ripcord $10 \mathrm{EC}) @ 1 \mathrm{ml} / \mathrm{l}$ of water, $\mathrm{T}_{2}$ = Spraying Chlorpyrifos + Cypermethrin (Nitro 505 EC) @ 1 ml/l of water, $\mathrm{T}_{3}=$ Spraying Lambda Cyhalothrin (Reeva $2.5 \mathrm{EC}$ ) @ $1 \mathrm{ml} / 1$ of water, $\mathrm{T}_{4}=$ Spraying Dimethoate (Tafgor $40 \mathrm{EC}$ ) @ $2 \mathrm{ml} / \mathrm{l}$ of water, $\mathrm{T}_{5}=$ Spraying Thiamethoxam + Chlorantraneliprol (Voliam flexi $300 \mathrm{SC}$ ) @ $0.5 \mathrm{ml} / 1$ of water, $\mathrm{T}_{6}=$ Spraying Emamectin Benzoate (Wonder $5 \mathrm{G}$ ) @ $1 \mathrm{~g} / \mathrm{l}, \mathrm{T}_{7}=$ Spraying Fipronil (Regent 50 $\mathrm{SC}$ ) @ $0.5 \mathrm{ml} / 1$ of water $\mathrm{T}_{8}=$ Spraying Imidachloprid (Imitaf $20 \mathrm{SL}$ ) @ $0.5 \mathrm{ml} / 1$ of water and $\mathrm{T}_{9}=$ Untreated control (water spray)

The experiment was laid out in randomized complete block design (RCBD) with three replications. The treatments were randomly allotted in each block. The unit plot size was $3 \mathrm{~m} \mathrm{X} 4 \mathrm{~m}$ with a distance of $1 \mathrm{~m}$ between the plots and $1.5 \mathrm{~m}$ between the replications. The seeds of BARI Mung 6 were sown on March 28 in rows with the spacing of $30 \mathrm{~cm}$ in both the seasons. The plant populations were maintained constant by keeping plant to plant distance $7 \mathrm{~cm}$. Urea, triple super phosphate and muriate of potash fertilizers were applied @ 40-90-40 kg/ha in both the seasons. But in $2014,7.5 \mathrm{~kg} / \mathrm{ha}$ boric acid was applied during final land preparation for reducing flower shedding and increasing pod setting with higher number of seed setting.

Three sprays were done, first at 20 days after sowing (DAS) when plants were in active vegetative growth stage (i.e., two trifoliate leaf stage) against leaf feeding and sucking insect pests. Second spray was done at $100 \%$ flowering stage (35 DAS) and the third at $100 \%$ podding stage (42 DAS) for flower thrips and pod borers because both the pests appeared that time. 
The population data for thrips in flowers were collected before spraying and one day after spraying. Thrips population was assessed from 20 opened flowers which were randomly collected from two rows of each side of the plot avoiding border and central four rows. The collected flowers were immediately opened on the white paper board and counted the adult and immature thrips present in the flowers. Central four rows were kept undisturbed for recording yield data.

Percentage of leaf area damaged by flea beetle was determined by eye estimation.

At the maturity, all pods were collected from 10 randomly selected plants from central four rows of each plot and examined. The infested (bored) and total numbers of pods were counted and the per cent pod infestation was calculated.

For recording stemfly infestation, ten mature plants were randomly selected also uprooted from two rows from each side of the plot avoiding border rows of each plot. The plants were brought to the laboratory and dissected the stem of each plant for determining the tunnel produced by stemfly larvae. Percentage of stemfly infestation was determined on the basis of stem tunneling.

The pods of central four rows of each plot comprising $4.8 \mathrm{~m}^{2}(1.2 \mathrm{~m} \mathrm{X} 4 \mathrm{~m})$ area were harvested. The pods were then threshed; grains were and. The grains obtained from each plot were cleaned, sun dried and converted into $\mathrm{kg} / \mathrm{ha}$.

The experimental data were analyzed by MSTAT-C software. The per cent infestation data were transformed by square root and arc sine transformation as needed for statistical analysis. Mean comparisons for treatment parameters were compared using Duncan's Multiple Range Test at 5\% level of significance.

The marginal benefit cost ratio (MBCR) was calculated on the basis of prevailing market prices of mungbean and cost of insecticidal spraying. Marginal benefit cost ratio was calculated as follows:

$$
\text { Marginal BCR }=\frac{\text { Benefit over control }}{\text { Cost of treatment }}
$$

\section{Results and Discussion}

\section{Effect of insecticides on flower infestation and thrips population}

Spraying of synthetic insecticides reduced flower infestation and thrips population significantly (Table $1 \& 2$ ). During 2013, after one day of spray application, the lowest number of infested flower (1.67/20 flowers) was observed in Imitaf sprayed plots which was statistically identical to Regent, Nitro, Ripcord, Voliam flexi and Tafgor. More than $80 \%$ flower infestation reduction was observed in Imitaf and Regent sprayed plots. Accordingly the lowest number of thrips (2.00/20 flowers) was observed in Imitaf sprayed plots which was statistically similar to Regent, Nitro, Ripcord and Reeva. All insecticides reduced more than $80 \%$ thrips population but Voliam flexi reduced little beat less (Table 1). 
In 2014, after one day of spray application, the lowest number of infested flower $(0.83 / 20$ flowers) was observed in Imitaf sprayed plots which was statistically identical to Nitro, Regent, Voliam flexi, Reeva and Tafgor. Like previous year Imitaf also reduced more than $80 \%$ flower infestation. Accordingly the lowest number of thrips (1.33/20 flowers) was observed in Imitaf sprayed plots which was statistically at par with Regent. Imitaf reduced more than $80 \%$ thrips population also (Table 2). These findings were agreed with the findings of Bhede et al. (2008) who reported the best effect of Imidachloprid for control of thrips in chilli. Hossain et. al. (2013) cited the best efficacy of Fipronil (Regent 50 SC) in managing thrips of onion with highest benifit. Hossain et al. (2011) and Hossain (2014) also found the best results of Imidachloprid (Imitaf 20 SL) to reduce flower infestation and suppression of thrips population in mungbean flowers.

Effects of insecticides on the incidence of stemfly, flea beetle and pod borers

Stemfly infestation varied depending on the efficacy of the insecticides. During cropping season of 2013, stemfly infestation among different treatments was non significant but varied 40.67 to $63.33 \%$ (Table 3 ). The lowest infestation $(40.67 \%)$ was found in Voliam flexi sprayed plots and the highest (63.33\%) was observed in untreated control plots.

In 2014, stemfly infestation significantly varied among the treatments. It ranged 40.00 to $80.00 \%$ (Table 3). The lowest infestation (40.00\%) was found in Regent sprayed plots which were statistically similar to Voliam flexi, Wonder and Reeva. The highest $(80.00 \%)$ was observed in untreated control plots.

Leaf area damaged by flea beetle was also varied among the insecticidal sprays. During 2013, it was non significant and ranged from 5.33 to $9.67 \%$ (Table 3). The lowest percentage of leaf area damaged by flea beetle (5.33\%) was observed in Voliam flexi, Regent, and Reeva treated plots and the highest was in untreated plots.

But in 2014 , leaf area damaged by flea beetle was significantly varied and ranged from 3.00 to $18.00 \%$ (Table 3). The lowest percentage of leaf area damaged by flea beetle $(3.00 \%)$ was observed in Voliam flexi followed by Wonder and the highest (18.00\%) was in untreated plots.

Pod borer infestation was low to moderate but varied significantly among the efficacy of the treatments. During 2013, pod infestation was low and varied from $1.02-8.02 \%$ (Table 3). The lowest pod borer infestation (1.02\%) was found in Voliam flexi sprayed plots which were statistically similar to Reeva, Nitro, Dimethoate, Wonder, Imitaf and Regent. The highest pod infestation (8.02\%) was found in untreated plots.

In 2014, pod borer infestation was moderate and it varied from $3.10-10.64 \%$ (Table 3). The lowest pod borer infestation $(3.10 \%)$ was found in Voliam flexi sprayed plots which were statistically similar to Wonder, Regent, Nitro and Tafgor. The highest pod infestation $(10.642 \%)$ was found in untreated plots. 
EFFICACY OF SOME INSECTICIDES AGAINST INSECT PESTS

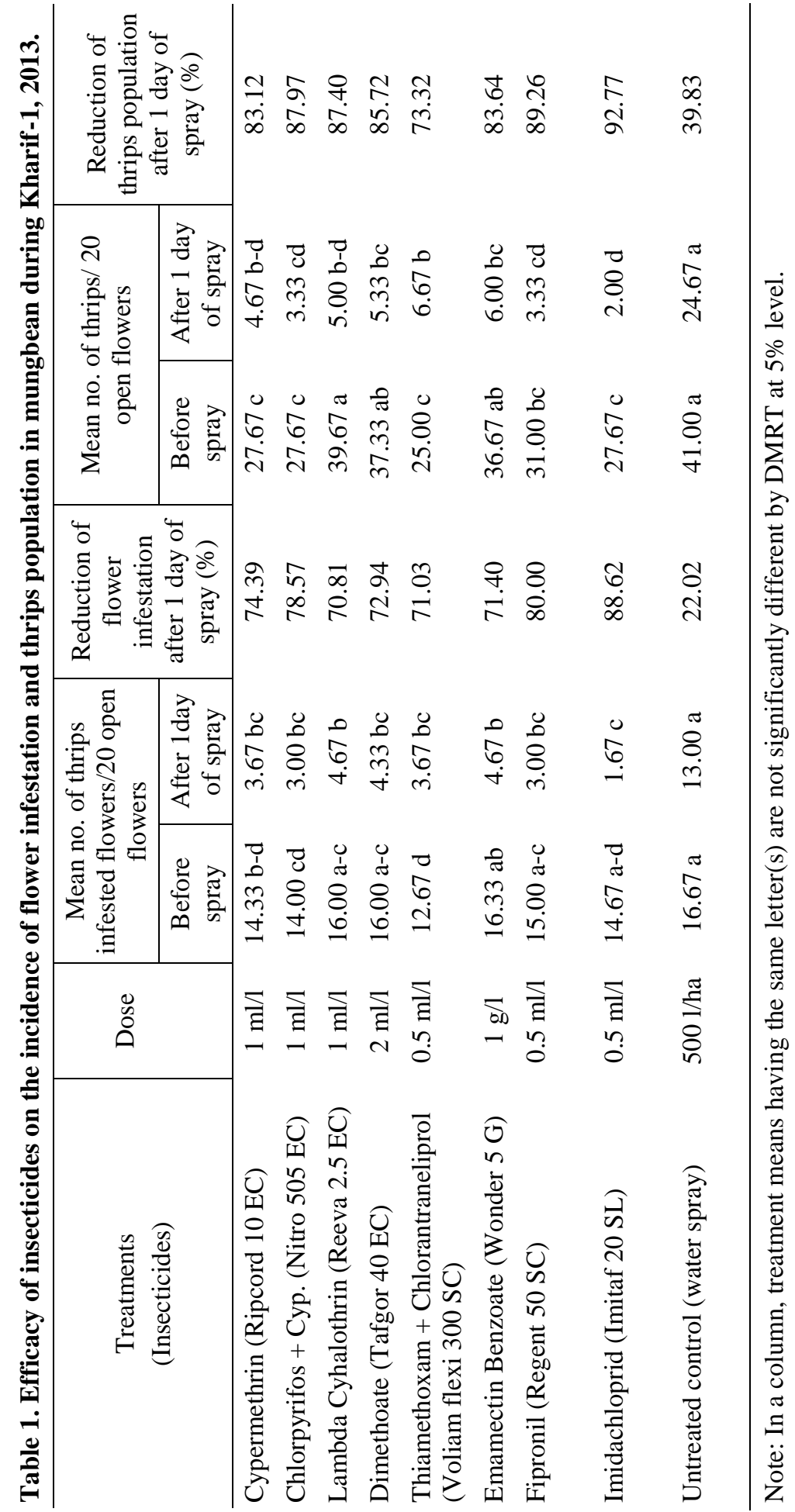


EFFICACY OF SOME INSECTICIDES AGAINST INSECT PESTS

663

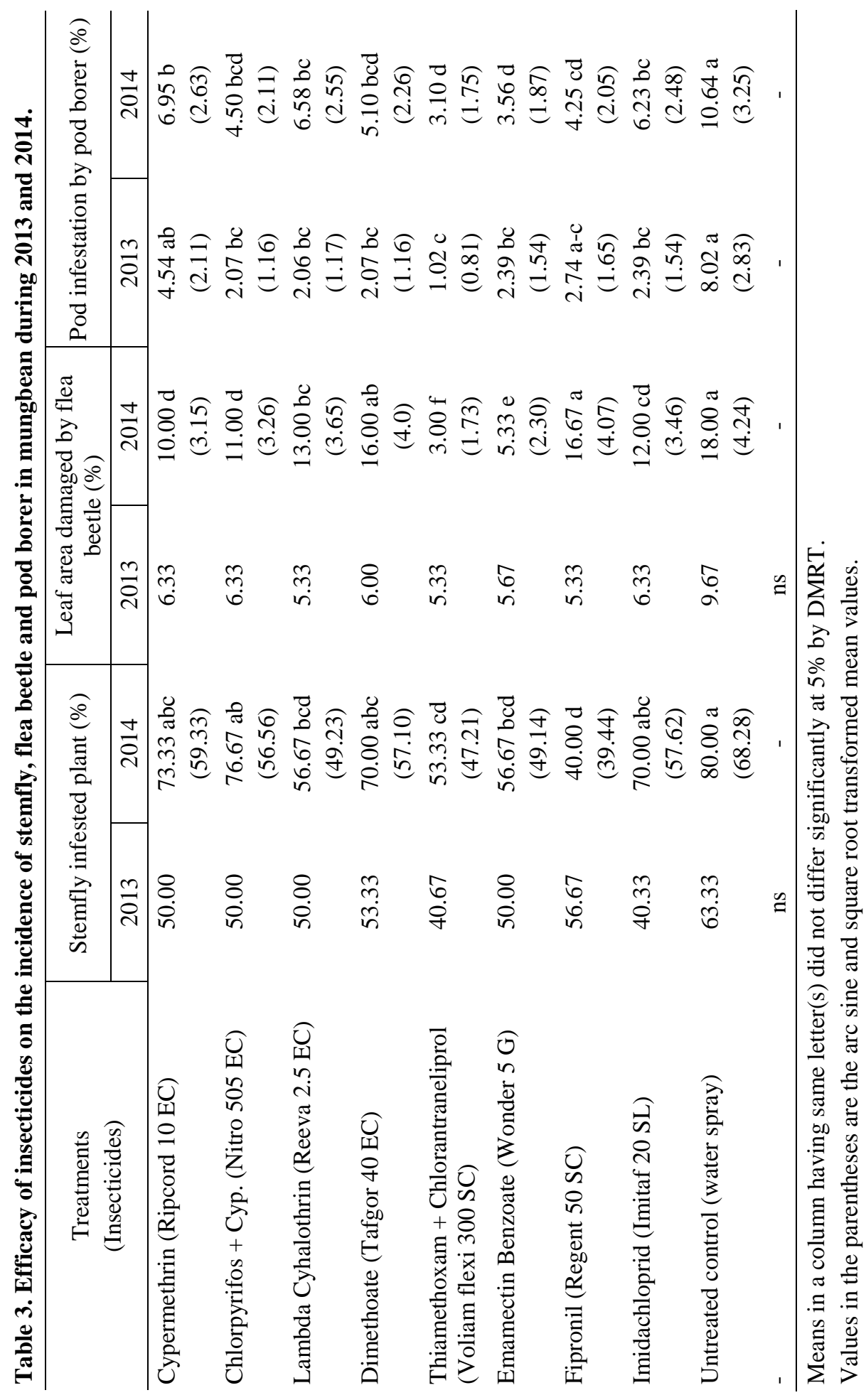


In both the years Voliam flexi performed the best in suppressing pod borer infestation. These findings agreed with the findings of Rouf and Islam (2012) and Hossain (2014) who reported that the best efficacy of Voliam flexi in controlling pod borers of mungbean.

\section{Yield, return and marginal benefit cost ratio (MBCR)}

Yield of mungbean varied significantly with the level of insect pest's infestation depending on the efficacy of different insecticides (Table 4). During 2013, the highest yield (1570 kg/ha) obtained from Regent sprayed plots which was statistically identical to Wonder, Tafgor, Voliam flexi and Imitaf followed by Ripcord, Nitro and Reeva. The lowest yield (1166 kg/ha) was recorded from untreated control plots.

But in 2014, the highest yield (2347 kg/ha) obtained from Voliam flexi sprayed plots which was statistically identical to Tafgor and Wonder followed by Regent, Ripcord and Imitaf. The lowest yield $(1701 \mathrm{~kg} / \mathrm{ha})$ was recorded from untreated control plots (Table 3). Considering two years average yield Voliam flexi provided the highest. Again, it is apparent that yield of mungbean was higher in kharif-I of 2014 than that of 2013. This might be due to the less thrips infestation with relatively favourable weather condition prevailing in kharif-I of 2014 compared to 2013 and also with boric acid application during 2014 cropping season might have some effect to produce more pods and seeds which influencing higher yield in later season. Alam et. al. 2010, Quddus et. al. 2011 and Abou EL-Yazied and Mady 2012 cited the positive effect of boron application to increase yield of mungbean. They reported that application of boric acid increased number of formed flowers, setted pods per plant, seed yields, as well as reduced shedding of flowers and pods.

Return and marginal benefit cost ratio are also presented in Table 4. The net return and marginal benefit cost ratio was varied depending on cost of insecticidal application. During 2013, the highest net return (Tk 21390/ha) was recorded from Regent sprayed plots followed by Wonder (Tk 15780/ha). And accordingly the highest monetary benefit (MBCR 7.51) come from Regent sprayed plots. But the second highest benefit (MBCR 4.78) obtained from Imitaf followed by Tafgor (MBCR 4.07). Due to higher cost of Wonder and Voliam flexi profit margin goes down and showed lower MBCR.

For each taka spent, Regent gave profit of Tk 7.51 as against Tk 4.78, Tk 4.07, Tk 2.77, Tk 2.43, Tk. 2.01, Tk. 1.98 and Tk. 1.48 in Regent, Imitaf, Tafgor, Wonder, Ripcord, Voliam flexi, Reeva and Nitro, respectively.

During 2014, the highest net return (Tk 33060/ha) was recorded from Voliam flexi sprayed plots followed by Tafgor, Wonder, Regent, Ripcord and Imitaf. But the highest monetary benefit (MBCR 7.34) also comes from Regent sprayed plots followed by Tafgor, Imitaf, Ripcord, Voliam flexi and Wonder. Though the Voliam flexi offered the highest net return but its higher cost broad down the profit margin and showed lower MBCR. 


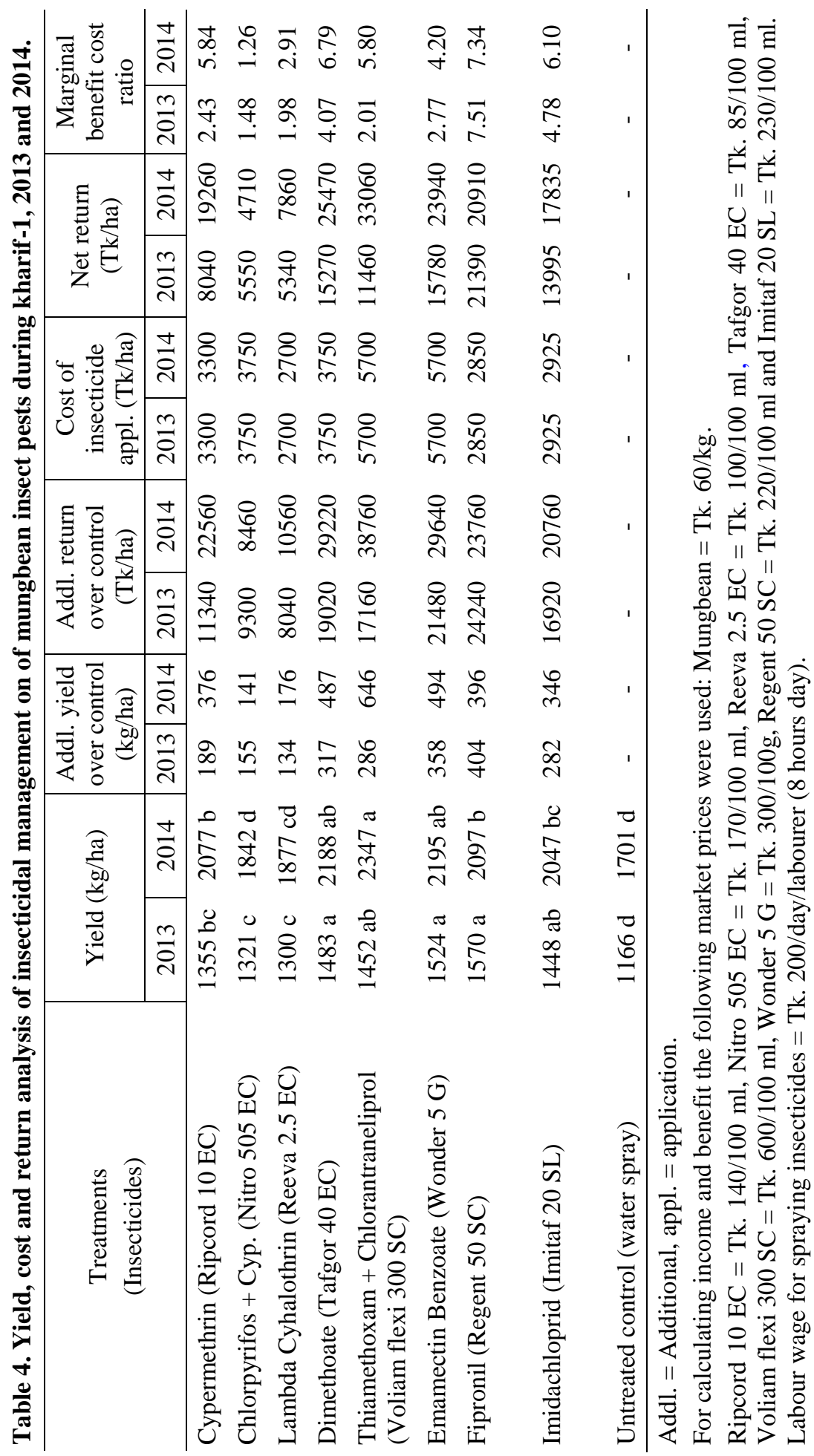


For each taka spent, Regent gave profit of Tk 7.34 as against Tk 6.79, Tk 6.10, Tk 5.84, Tk 5.80, Tk. 4.20, Tk. 2.91 and Tk. 1.26 in Tafgor, Imitaf, Ripcord, Voliam flexi, Wonder, Reeva, and Nitro, respectively.

These profit findings showed very encouraging results of spraying in mungbean. Spraying of Imidachloprid (Imitaf $20 \mathrm{SL}$ ) @ $0.5 \mathrm{ml} / \mathrm{l}$ of water showed the best efficacy in reducing flower infestation and thrips population followed by Fipronil (Regent 50 SC). Spraying of Thiamethoxam + Chlorantraneliprol (Voliam flexi $300 \mathrm{SC}) @ 0.5 \mathrm{ml} / \mathrm{l}$ of water showed the best efficacy in reducing pod borer and flea beetle infestation. Spraying of Fipronil (Regent 50 SC) performed best against stemfly infestation. Therefore, considering overall efficacy and benefit spraying of Fipronil (Regent $50 \mathrm{SC}$ ) at the concentration of $0.5 \mathrm{ml} / 1$ is the most profitable insecticidal management approach against insect pests of mungbean in Bangladesh followed by Imidachloprid (Imitaf. 20 SL) at the same dose.

\section{Acknowledgements}

The author is thankful to ACIAR (Rice-Pulse) project for providing necessary facilities to developing this program and conducts the study.

\section{References}

Alam, M.R., M.A. Ali, S. Rafiquzzaman, B. Ahmed and M. Bazzaz. 2010. Effect of phosphorus and boron on the performance of summer mungbean in high Ganges river floodplain soil. J. Agrofor. Environ. 3(2): 183-186.

Abou EL-Yazied, A. and M.A. Mady. 2012. Effect of boron and yeast extract foliar application on growth, pod setting and both green pod and seed yield of broad bean (Vicia faba L.). J. Appl. Sci. Res. 8(2): 1240-1251.

Bakr, M.A. 1998. Disease and insect management of mungbean and blackgram. Resource manual-Location specific technologies for rice based cropping systems under irrigated conditions. Thana cereal technology transfer and identification project, Dhaka. Pp.201-205.

Bhede, B.V., D.S. Suryawanshi and D.G. More. 2008. Population dynamics and bioefficacy of newer insecticide against chilli thrips, Scirtothrips dorsalis (Hood). Indian J. Entomol. 70(3): 223-226.

Chhabra, K.S. and B.S. Kooner. 1985. Loss of summer mungbean due to insect pests in Punjub. Indian J. Entomol. 47(1):103-105.

Hossain, M.A., M.S. Zaman and M.J. Alam. 2011. Management of flower thrips and pod borers in mungbean, Vigna radiata L.). Bangladesh J. Life Sci. 23(2): 79-86.

Hossain, M.M., M.M. Kamal and D. Sarker. 2013. Integrated management of onion thrips (Thrips tabaci). Annual Report 2012-2013. Entomology Division, Bangladesh Agricultural Research Institute, Gazipur, Bangladesh. Pp. 157-159.

Hossain, M.A. 2014. Development of IPM practices for the control of flower thrips and pod borers in mungbean (Vigna radiata L.). Bull. Inst. Trop. Agr., Kyushu Univ. 37: $85-92$. 
Lal, S.S. 1985. A review of insect pests of mungbean and their control on India. Trop. Pest Management 31(2): 105-114.

Poehlman, J.M. 1991. The Mungbean. Oxford and IBH Publ. Co. Pvt. Ltd., New Delhi, Bombay and Calcutta, $292 \mathrm{Pp}$.

Quddus, M. A., M. H. Rashid, M. A. Hossain and H.M. Naser. 2011. Effect of zinc and boron on yield and yield contributing characters of mungbean in low ganges river floodplain soil at Madaripur, Bangladesh.Bangladesh. J. Agril. Res. 36(1): 75-85.

Rahman, M.M., M.A. Bakr, M.F. Mia, K.M. Idris, C.L.L. Gowda, J. Kumar, U.K. Dev, M.A. Malek and A. Sobhan. 2000. Legumes in Bangladesh. In: Johansen, C., Duxbury, J.M., Virmani, S.M., Gowda, C.L.L., Pande, S. and Joshi, P.K. (eds.). Legumes in rice and wheat cropping systems of the Indo-Gangetic Plain Constraints and opportunities. Patancheru 502 324, Andhra Pradesh, India: ICRISAT and Ithaca, New York, USA: Cornell University. 230 Pp.

Rouf, F.M.A. and M.I. Islam. 2012. Efficacy of some insecticides and btanical pesticides for controlling pod borer complex of mungbean. Annual Report 2011-2012. Entomology Division, Bangladesh Agricultural Research Institute, Gazipur, Bangladesh. Pp. 19-21. 